○特集 生体膜関連シンポジウム「手法で語る生体膜研究…今昔」

\title{
薬物トランスポータ研究と今後の展開
}

\author{
乾 賢一*・寺田智祐 \\ 京都大学 医学部附属病院 薬剤部 \\ ₹ 606-8507 京都府京都市左京区聖護院川原町 54
}

\section{Drug Transporter Research and Future Perspective}

\author{
Ken-ichi Inui * and Tomohiro Terada \\ Department of Pharmacy, Kyoto University Hospital \\ Sakyo-ku, Kyoto 606-8507, Japan
}

Currently, it is widely recognized that drug transporters play important roles as major determinants for pharmacokinetic properties of drugs. During about 30 years, we have investigated membrane transport of drugs via carriers, with taking various novel techniques such as membrane vesicles and molecular biology into this research field, and reported some important novel findings on the intestinal absorption and renal excretion of drugs. Furthermore, we have developed clinical research of drug transporters to accomplish our motto "From Bench to Bedside". In this review, we would like to look back on the history of drug transporter research, mainly focusing on our studies, and describe the future perspectives.

Key words : drug transporter / pharmacogenetics / absorption / excretion

\section{1. はじめに}

生体に投与された薬物は，投与部位から循環血中 への移行（吸収）とそれに続く臓器分布を経て, 最 終的に体外へ排泄される (Fig. 1)。これら薬物動態 の諸過程を規定する重要な因子として, 個々の臓器 における生体膜（形質膜）透過性が挙げられる. 生 体膜は脂質二分子層によって構成されているため, 脂溶性薬物は受動拡散によって生体膜を透過するが, 低脂溶性のイオン性薬物は, 生体膜に発現している トランスポータによって膜透過が制御されている. 薬物トランスポータとして機能する場合には, 大別 して次の 2 つケースが考えられる. すなわち, 生体 にとって必要な成分を輸送するために備わっている トランスポータが, 薬物を誤って基質として認識し 輸送する場合, 及び生体の不要物（内因性老廃物な

* Corresponding Author

Tel : 075-751-3577

Fax : 075-751-4207

E-mail : inui@kuhp.kyoto-u.ac.jp
ど）を体内から排除するために備わっているトラン スポータが, 生体異物である薬物を本来の基質とし て輸送する場合である. 我々は, 約 30 年前, すなわ ち薬物生体内移行の研究が主に個体・組織レベルで 行われ, 薬物膜輸送が主に受動拡散によって起こる と考えられていた時代から，いち早く担体を介した 薬物輸送研究に取り組んできた。また, 薬物トラン スポータ研究に, 分子生物学やゲノム遺伝学などの 研究手法を早期に導入し, 薬物の腸管吸収や腎排泄 機構に関与するトランスポータ群の分子同定, 膜輸 送の機序解明, 発現制御機構の解明, 遺伝子多型の 影響など, トランスポータを介した薬物の膜透過現 象を様々な観点から究明してきた（Fig. 2). さらに 最近では, このようにして得られた基礎研究の成果 を臨床に還元するため, “From Bench to Bedside”を モットーにした臨床展開を進めている.

本稿では, 薬物トランスポータ研究の歴史を振り 返り, 各薬物トランスポータの特徴について我々の 研究成果を中心に概説する. さらに, 薬物トランス ポータ分子情報を活用した臨床応用について紹介す 


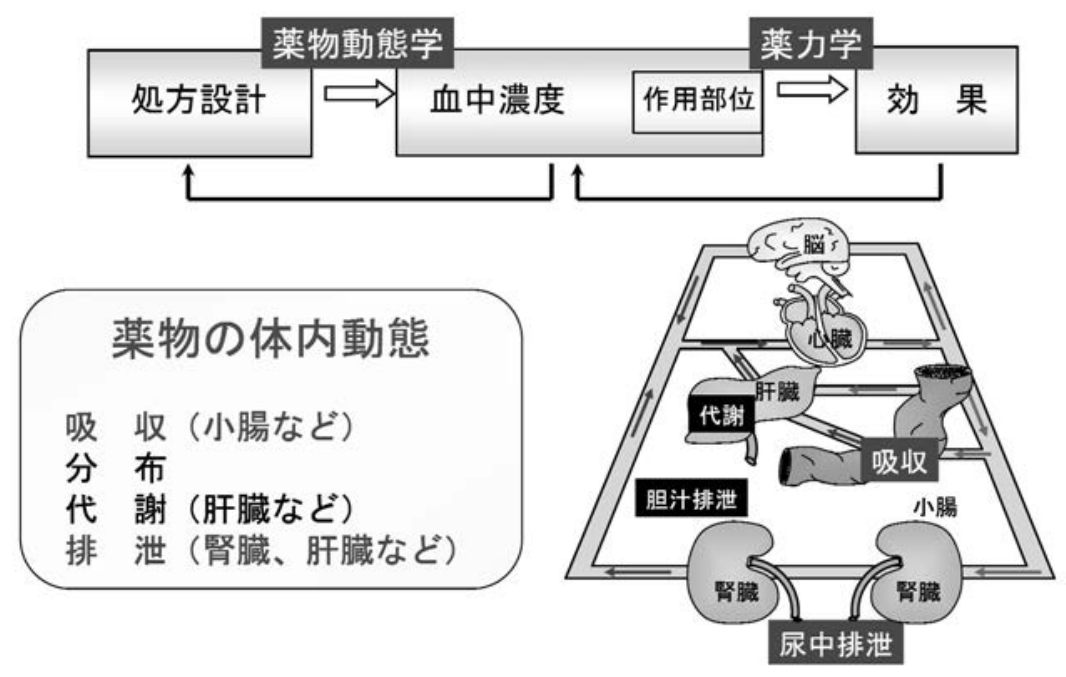

Fig. 1 Pharmacokinetics and pharmacodynamics. Drug transporters play pivotal roles as key determinants for pharmacokinetic processes such as absorption, distribution and excretion.

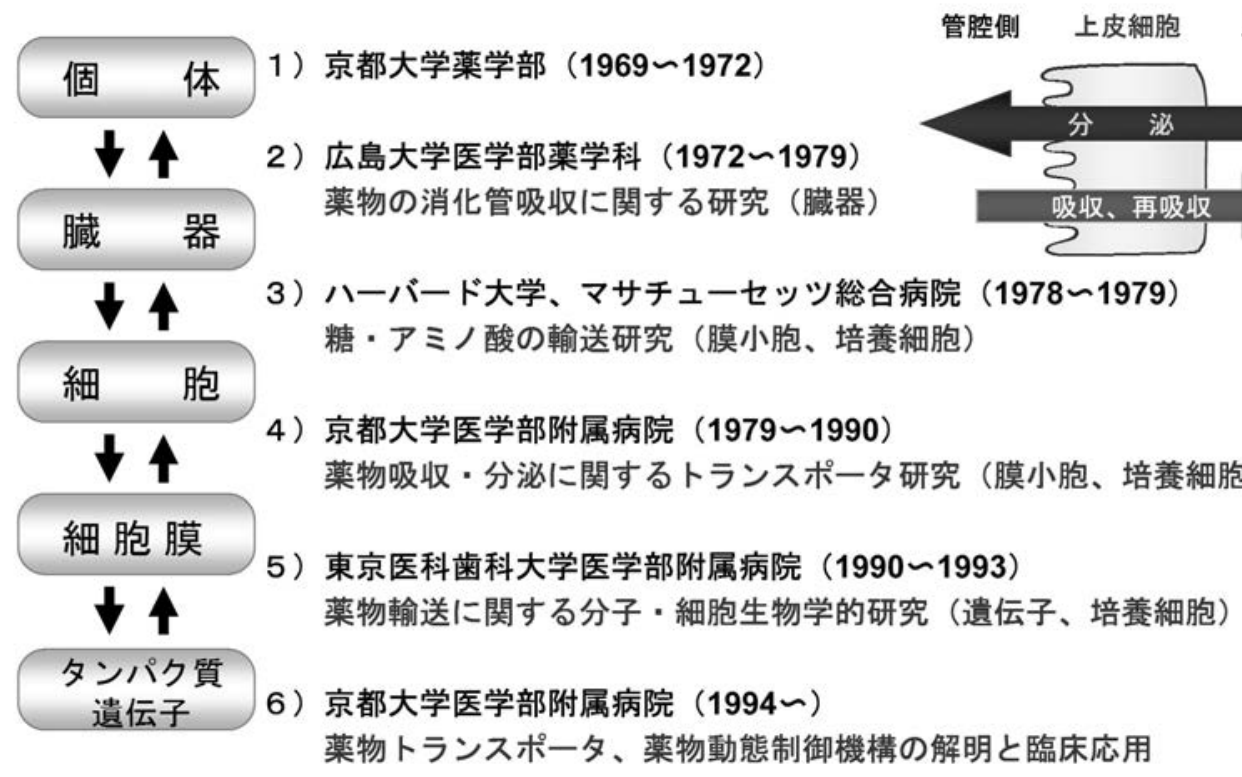

Fig. 2 Progress in our drug transporter research.

ると共に，今後の展望について述べてみたい.

\section{2. 膜小胞系および培養細胞系を用いた薬物 輸送研究}

1970年代における薬物の膜輸送現象は, 薬物の荷 電状態と脂溶性に基づいた $\mathrm{pH}$ 分配仮説を中心に考え られていた。 しかし， $\mathrm{pH}$ 分配仮説に従わない薬物も 存在し，そのメカニズムを説明するため薬物輸送担 体の存在が想定されていた. しかし当時の薬物生体 内移行の研究は, 主に個体レベル, 組織レベルで行 われており, 膜レベルでの輸送現象を詳細に解析す るための精巧な研究手法はなかった。 そこで, 留学
先で習得し, 主に糖やアミノ酸等の栄養物質の輸送 実験で利用されていた膜小胞系や培養細胞系の実験 手法を薬物輸送研究に取り入れ, 担体を介した薬物 輸送のメカニズム解明に取り組んだ. 実験の立ち上 げまでに非常に多くの苦労を伴ったが，腎尿細管有 機カチオン及び有機アニオン輸送系や小腸 $\mathrm{H}^{+} /$ペプチ ド共輸送系が広範な基質認識特性を有し, 膜内外の エネルギー勾配を巧みに利用した能動輸送系である ことを実証することができた ${ }^{123)}$.さらに，LLC$\mathrm{PK}_{1}$ など培養上皮細胞を初めて薬物動態学・毒性学 研究に導入し, 経細胞輸送特性や活性調節機構を細 胞レベルで明らかにした ${ }^{4,5)}$ 。これら培養細胞系は, 薬物動態研究や薬物吸収・排泄スクリーニングにお 
ける in vitroモデル系として, 現在幅広く利用されて いる.

\section{3. 薬物トランスポータの構造・機能・調節 に関する研究}

膜小胞系や培養細胞系で得られた知見を分子的に 解明するため, 薬物輸送研究に分子生物学的手法を 取り入れ，遺伝子クローニングを試みた。 その結果, これまで新規遺伝子 8 種類を含む 11 種類のトランス ポータ遺伝子のクローニングを報告し，これにはぺ プチドトランスポータ (rPEPT1, rPEPT2), 有機カ チオントランスポータ (rOCT2, hOCT2-A), $\mathrm{H}^{+}$/有 機カチオンアンチポータ（rMATE1, hMATE2-K）な どが含まれる。これらのトランスポータを中心とし $\tau$, 基質認識特性, 構造 - 機能活性相関, 調節機構 など薬物トランスポータの生理学的・薬物動態学的 役割を分子面から解明してきた，以下に，種々薬物 トランスポータの概要について紹介する.

\subsection{ABCトランスポータ（P-糖タンパク質／ MDR1など)6,7)}

$\mathrm{ABC}$ トランスポータは, ATPの加水分解エネルギ 一を利用して細胞内から細胞外への薬物排出を営む トランスポータであり, このファミリーには $\mathrm{P}-$ 糖タ ンパク質 (Pgp), multidrug resistance associated protein (MRP) ファミリーなどが属している.これらの トランスポータは，もともとがん細胞から多戍耐性 因子として同定されたものであるが，がん細胞のみ ならず正常組織（小腸, 肝臓, 腎臓, 脳など) にも 発現し, 化学構造や作用機序の異なる多様な薬物 （抗がん剂，免疫抑制剤など）を輸送している.Pgp は中性・カチオン性の高脂溶性薬物を代表的基質と するのに対して，MRPファミリーはアニオン性の高 脂溶性薬物を代表的基質とする. Pgp/MDR1は最も 研究の進んでいる薬物トランスポータの一つであり, 構造・活性相関, 発現制御機構等の基礎研究のみな らず，薬物相互作用や遺伝子多型，さらには後述す る個別化薬物療法への応用など多くの臨床研究も実 施されている.

\section{2 ペプチドトランスポータ (PEPT) ${ }^{8)}$}

ペプチドトランスポータには, PEPT1 と PEPT2の 2 つのアイソフォームが存在する. 両トランスポータ は, $\mathrm{H}^{+}$勾配を駆動力として, 小分子ペプチド（ジペ プチドやトリペプチド）や経口用 $\beta$-ラクタム抗生物 質などペプチド類似薬物を認識し輸送する．両トラ ンスポータの基質に対する親和性は大きく異なり,
PEPT1が低親和性型，また PEPT2 が高親和性型ペプ チドトランスポータとして機能している. PEPT1は 主に小腸の刷子縁膜に, またPEPT2 は主に腎臓の刷 子縁膜に発現し, ペプチド類似薬物の腸管吸収や腎 再吸収に寄与している，小腸に発現する PEPT1は, ペプチド結合を持たない化合物をも輸送することが 見出され, 難吸収性薬物の吸収改善を目指したDDS への応用が注目されている. 例えば, バラシクロビ ルは抗ウイルス薬アシクロビルの経口吸収性を改善 するために開発されたプロドラッグであり，アシク ロビルにバリンをエステル結合させた構造を有して いる ${ }^{9)}$.アシクロビルは 1 日 5 回の経口投与が必要で あったが，バラシクロビルは PEPT1によって良好に 輸送されるため, 1 日 $2 \sim 3$ 回の経口投与で充分な血 中濃度が得られている. その他, 抗ウイルス薬バル ガンシクロビル 10) や，低血圧治療薬ミドドリン 11）も アミノ酸修飾することによって PEPT1の基質となる. この様に, PEPT1は DDS標的分子としての有用性が 臨床的にも実証され, 今後も同様の戦略に基づく難 吸収性薬物のプロドラッグ開発が期待されるである う。また最近では, PEPT1の発現制御機構に関する 知見も集積しつつあり, 絶食に伴う PEPT1の発現上 昇には遊離脂肪酸を生理的リガンドとする核内受容 体 PPAR $\alpha^{12)}$ が，またPEPT1の日周リズムには時計 遺伝子 $\mathrm{DBP}^{13)}$ が関与している.

\section{3 有機カチオントランスポータ (OCT) 14, 15)}

腎蔵における排泄は, 糸球体濾過と尿細管分泌よ り構成されるが, 薬物や代謝産物などの有機イオン は主に近位尿細管での分泌によって尿中に排泄され る. 近位尿細管での分泌過程は経上皮細胞的に進行 し，血管側側底膜を介する細胞内への取り込みと， 管腔側刷子縁膜を介する細胞内から管腔への放出と いう二段階の膜輸送によって支配されている (Fig. 3). 例えば, 有機カチオンは側底膜の膜電位依 存性有機カチオントランスポータ（OCT）によって 細胞内に運ばれ, さらに刷子縁膜の $\mathrm{H}^{+}$/有機カチオン アンチポータ（MATE）を介して能動的に管腔内へ 分泌されることが知られている.

OCTには OCT1, OCT2, OCT3のアイソフォーム があり, 腎臓, 肝臓, 胎盤などに発現している。 ヒ 卜腎臟では OCT2 が尿細管上皮細胞の側底膜に局在 し, 細胞内負の膜電位を駆動力として, カチオン性 薬物（シメチジン, プロカインアミドなど）の血液 から尿細管上皮細胞内への取り込み過程を媒介して いる.これらの薬物は, 刷子縁膜に存在する MATE によって細胞内から管腔中へ輸送され，尿細管分泌 が達成される (後述)。また, OCT2 は腎毒性を示す 


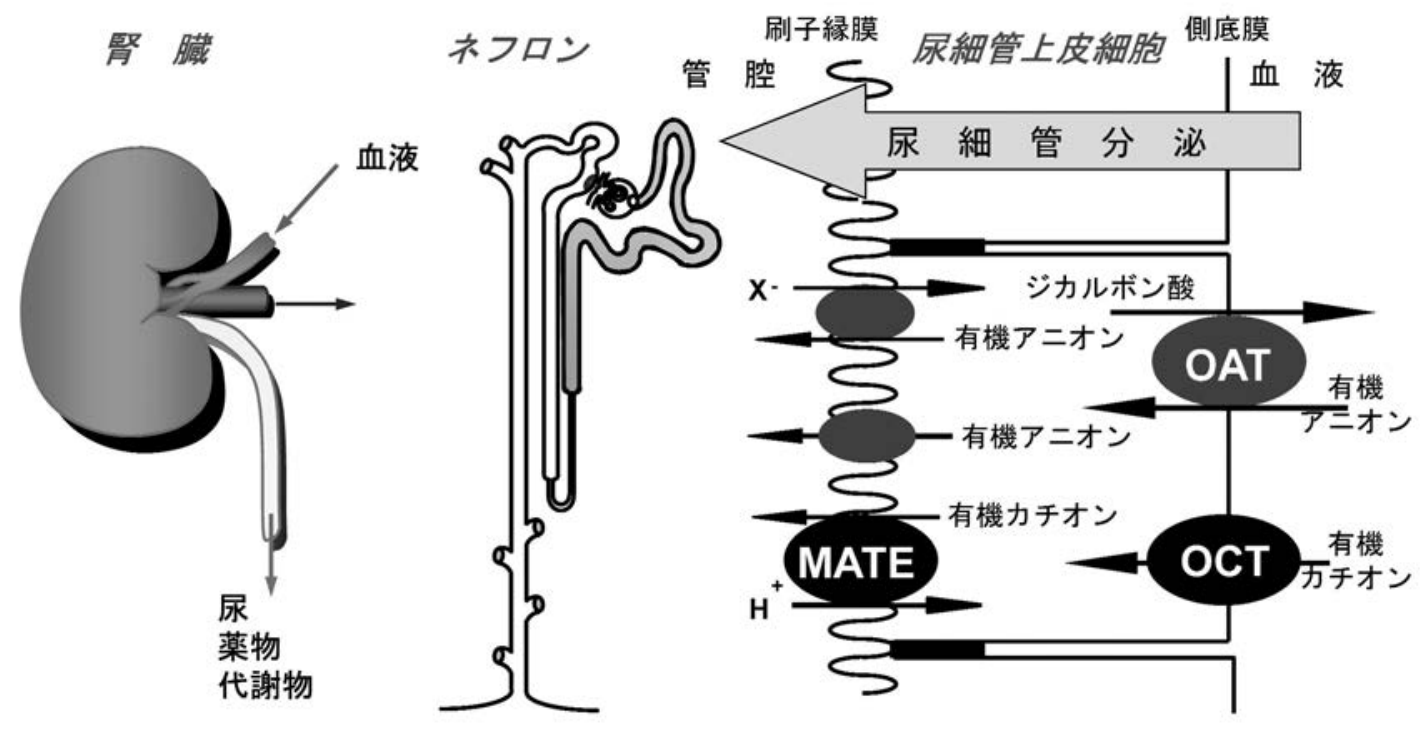

Fig. 3 Renal secretion of ionic drugs.

抗がん剂シスプラチンを輸送し，シスプラチンの高 い腎移行性に寄与している ${ }^{16)}$ 。 シスプラチンは MATEによって輸送されないため, 腎に蓄積し腎毒 性を示すと考えられている ${ }^{17)}$ 。これらの薬物に加え て, 糸球体濾過速度マーカーとして臨床的に用いら れている生体内物質クレアチニンが， OCT2を介して 輸送されることが明らかになった ${ }^{18)}$ ．カチオン性薬 物の併用により OCT2を介したクレアチニン輸送が 阻害され, 血清クレアチニンの上昇やクレアチニン クリアランスの低下を招き，腎機能を過小評価する 危険性があると考えられる。

\section{$3.4 \mathrm{H}^{+}$/有機カチオンアンチポータ (MATE) ${ }^{19)}$}

$\mathrm{H}^{+}$/有機カチオンアンチポータの分子実体は長年不 明であり，その同定が待ち望まれていた。2005年に 岡山大学の森山らのグループによって, 大腸菌の多 剂耐性に関与するMATEのほ乳類ホモログとして, ヒト及びマウスの MATE1並びに MATE2 が同定され た 20). MATE1の臟器分布，膜局在並びに輸送特性な どから，本トランスポータが刷子縁膜において $\mathrm{H}^{+}$勾 配によって駆動される輸送系として機能しているこ とが示された．その後，我々の研究室を含め複数の 研究室から, MATEの単離と機能解析が報告され, 本トランスポータが $\mathrm{H}^{+}$/有機カチオンアンチポータと して機能していることが実証されるに至った。しか し，最初に報告されたヒトMATE2 の機能や発現につ いては現在のところ明らかにされておらず，我々が 単離した MATE2-Kが輸送活性を有する唯一のアイ ソフォームとして知られている ${ }^{21)}$.

ヒト MATE1 mRNAは, 腎臓, 副腎 $>>$ 精巣 $>$ 骨 格筋，肝臓，子宮に，またヒト MATE2-Kは腎特異
的に発現している ${ }^{21)}$. MATE1並びに MATE2-Kは， OCT2 と類似の薬物認識特性を示し, OCT2を介して 取り込まれた薬物は MATE1やMATE2-Kを介して尿 細管管腔へ分泌されると考えられる。実際我々は, 有機カチオン輸送系を有していないMDCK細胞をホ ストとして MATE1/OCT2の共発現系を作製し，上述 した薬物が尿細管分泌に対応した方向選択的な輸送 を受けることを確認している.

刷子縁膜小胞を用いた輸送解析より, $\mathrm{H}^{+} /$有機力チ オンアンチポータに存在するシステイン (Cys) やヒ スチジン（His）残基が輸送機能に必須であることが 示されていた 22,23). またラット MATE1の輸送活性は, Cys残基修飾試薬によって顕著に低下することが報告 された ${ }^{24)}$.そこで，MATE1に存在するこれら必須ア ミノ酸残基の同定を試みたところ，MATE1の保存性 Cysのうち, 第 1 並びに第 3 番目の膜貫通領域に存在 する Cys 変異体, 並びに第 10 番目の膜貫通領域の His 変異体で輸送活性が低下した ${ }^{25)}$ 。また，Cysや Hisのアミノ酸修飾試薬処理に及ぼす基質の保護効果 について調べたところ, Cys 残基は基質の結合部位と して機能していることが示唆された.

\section{5 有機アニオントランスポータ（OAT） 14, 26)}

有機アニオントランスポータである OATには, OAT1から OAT4のアイソフォームが存在し，ヒト腎 臓では，OAT3>OAT1>OAT2，OAT4の順に発現 している ${ }^{27)}$. 興味深いことに, OAT1は前述の OCT1 と約 40\%のアミノ酸相同性を有し, OATと OCTは有 機イオントランスポータファミリーを形成している. これまで膜小胞や培養細胞を用いた輸送研究により, 血管側側底膜に存在する有機アニオントランスポー 


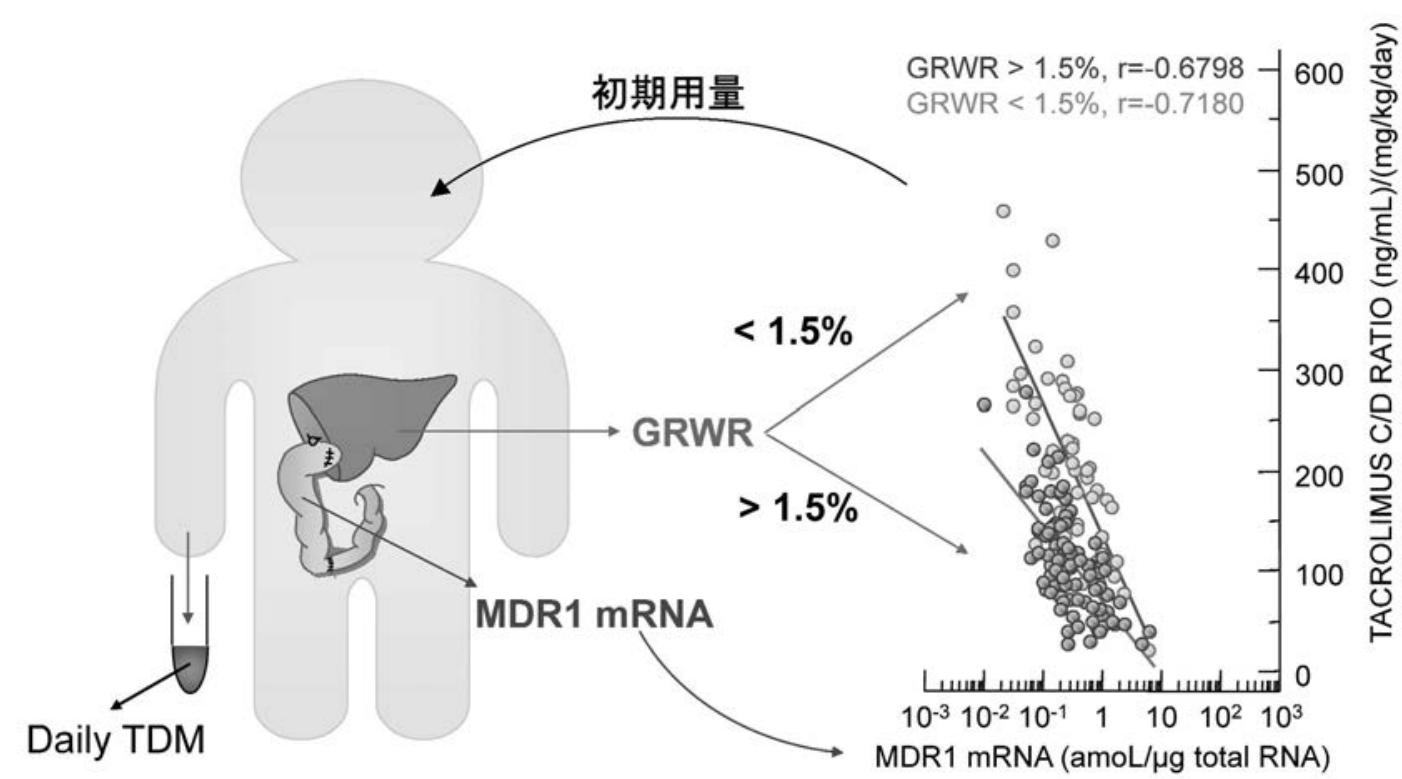

Fig. 4 Initial dosage adjustment of tacrolimus based on intestinal MDR1 mRNA level at surgery.

タはTCAサイクルの中間代謝産物として生じるジカ ルボン酸との交換輸送により, 血液中の有機アニオ ンの細胞内取り込みを媒介し，尿細管分泌の第一ス テップを担っていると考えられてきた. OAT1の機能 特性や免疫染色の結果はこれらの条件を満たすこと から, OAT1は側底膜に存在する有機アニオントラン スポータとして機能していると考えられる. OAT1は, 内因性物質としてプロスタグランジン E $2, \mathrm{cAMP}$, 尿酸, ジカルボン酸, 葉酸などを, また外因性物質 としては抗ウイルス薬, 非ステロイド性抗炎症薬, 利尿薬, 抗がん剤メソトレキサートなどを輸送し, 幅広い基質選択性を有している。 OAT3も，ジカルボ ン酸との交換輸送体であり近位尿細管上皮細胞の側 底膜に局在している. OAT3はセファロスポリン系抗 生物質や胆汁酸等のアニオン性物質を輸送する ${ }^{28,29)}$.

\section{4. 薬物トランスポータ研究の臨床展開}

移植医療に必須の免疫抑制剂タクロリムスは，バ イオアベイラビリティが低く, 個体間・個体内変動 が大きいため, 投与設計の難しい薬物である. そこ で, タクロリムス体内動態の個体間・個体内変動の 分子機序を解明するため, 小腸においてタクロリム スの吸収障壁として機能すると考えられる排出ポン プ P-糖タンパク質/MDR1及び薬物代謝酵素 CYP3A4 の発現量とタクロリムス血中濃度推移との比較解析 を行った。 その結果, 生体肝移植患者の小腸組織に おける MDR1 mRNA発現には個体間で約 100 倍の違 いが認められ，術後7日間における免疫抑制剂タクロ リムスの血中濃度／投与量の比とMDR1 mRNA発現
量との間に良好な逆相関があることを見出した ${ }^{30)}$. これは, 小腸 MDR1 mRNA発現量が, タクロリムス の吸収動態を規定する重要な因子であることを定量 的に実証したものであり, 現在, 個別化免疫抑制療 法の確立に活用している（Fig. 4） ${ }^{31)}$.

また，腎生検が施行された腎疾患患者について， 腎組織における有機アニオントランスポータ（OAT14）のmRNA量を測定し, 感染症予防のために投与さ れたアニオン性抗生物質セファゾリンの腎排泄速度 との相関について解析した. その結果, OAT3 mRNA 発現量のみがセファゾリンの消失速度定数と有意な 相関を示し, OAT3 mRNA発現量が薬物腎排泄速度 の規定因子であることが明らかになった ${ }^{32,33)}$. OAT3 mRNA 発現量に影響を及ぼすプロモーター領域の遺 伝子多型を検索したが, 個体差の要因となり得る遺 伝子多型は同定されなかった ${ }^{34)}$. 今後の課題として, 血液や尿サンプルなどを用いて非侵襲的に薬物トラ ンスポータの発現量を予測できるシステムの構築が 望まれる.

\section{5. 薬物トランスポータ研究の展望}

基礎研究では, 腎臓の刷子縁膜に発現する $\mathrm{H}^{+}$/有機 カチオンアンチポータがクローニングされ, 重要な 多くの役者は揃ってきたが, 未同定のトランスポー タもまだ残っている. 一番の大きな課題は, 薬物卜 ランスポータがどのように多くの薬物を認識し輸送 するかという分子メカニズムがほとんど分かってい ない点が挙げられる. 結晶構造解析などを通してこ の点が明らかになれば, 創薬などに有用な情報を提 


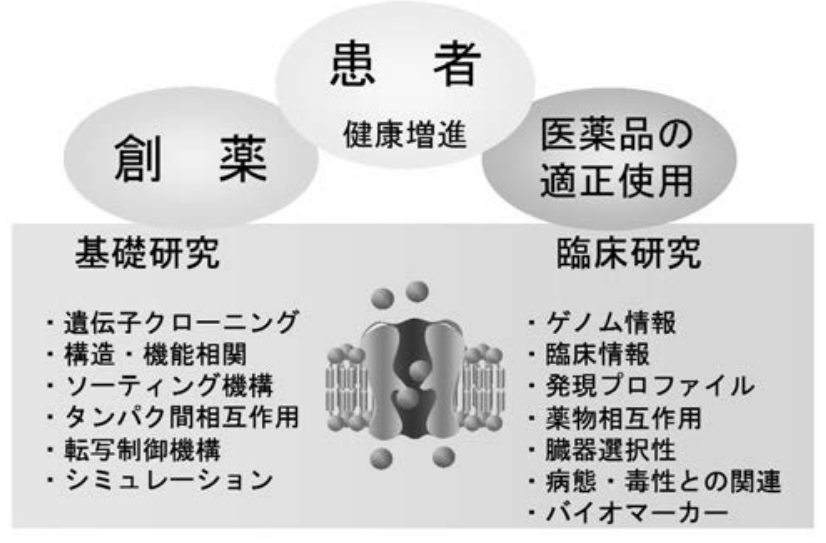

Fig. 5 Perspectives of drug transporter research.

供できるであろう。また薬物トランスポータの調 節・制御に関わる分子機構についてもまだまだ情報 は乏しいのが現状である。ささにシミュレーション によって各分子間のネットワークや，輸送機序，基 質認識特性を解析することも，今後益々重要になっ てくると思われる.

一方, 臨床研究では, 散在しているゲノム情報, 臨床情報, 発現情報を如何にインテグレートし, 医 薬品の適正使用に応用するかが最重要課題だと思わ れる. また臨床上問題となっている薬物相互作用, 蔵器選択性, 病態・毒性との関連についても, 基礎 的に究明するあるいは基礎研究の成果を応用するな ど，バランスの取れた研究 strategyが肝要であろう. さらに薬物治療の最適化を簡便に行うためのバイオ マーカーの探索も次の課題として挙げられる.

最終的にはこれらの研究成果をバイオインフォマ ティックスの手法を活用してシステム化し, 安心・ 安全な医療を提供することによって, 患者の健康増 進に寄与することが最終目標であると考えている (Fig. 5).

\section{6. おわりに}

「手法で語る生体膜研究…今昔」というシンポジ ウムのテーマのもと, 薬物トランスポータ研究の現 状と展望についてまとめてみた。 30 年近くの研究を 振り返ってみると, 当初は薬物トランスポータとい う概念すらなかった時代から, 現在では薬物トラン スポータの分子実体が明らかになったことは非常に 感慨深いものがある. しかし, 薬物トランスポータ 研究の成果を社会に還元するためには，まだまだ多 くの課題が残されており, “a little answer, more question”の感は拭えない. 今後も薬物トランスポータ研 究が着実に発展し, 多くの課題が少しでも早く解決 される日を期待している.

\section{文献}

1) Takano M, Inui $K$, Okano $T$, Saito $H$, Hori $R$ : Biochim. Biophys. Acta, 773, 113-124 (1984)

2) Okano T, Inui K, Maegawa H, Takano M, Hori R : J. Biol. Chem., 261, 14130-14134 (1986)

3) Ohoka K, Takano M, Okano T, Maeda S, Inui K, Hori R : Biol. Pharm. Bull., 16, 395-401 (1993)

4) Hori R, Yamamoto K, Saito H, Kohno M, Inui $\mathrm{K}: J$. Pharmacol. Exp. Ther., 230, $742-748$ (1984)

5) Saito H, Yamamoto M, Inui K, Hori R : Am. J. Physiol., 262, C59-C66 (1992)

6) Kimura Y, Matsuo M, Takahashi K, Saeki T, Kioka N, Amachi T, Ueda K : Curr. Drug Metab., 5, 1-10 (2004)

7) Haimeur A, Conseil G, Deeley RG, Cole SP : Curr. Drug Metab., 5, 21-53 (2004)

8) Terada T, Inui K : Curr. Drug Metab., 5, 85-94 (2004)

9) Han H, de Vrueh RL, Rhie JK, Covitz KM, Smith PL, Lee CP, Oh DM, Sadee W, Amidon GL : Pharm. Res., 15, 1154-1159 (1998)

10) Sugawara M, Huang W, Fei YJ, Leibach FH, Ganapathy V, Ganapathy ME : J. Pharm. Sci., 89, 781-789 (2000)

11) Tsuda $M$, Terada $T$, Irie $M$, Katsura $T$, Niida $A$, Tomita $K$, Fujii N, Inui K : J. Pharmacol. Exp. Ther., 318, 455-460 (2006)

12) Shimakura J, Terada $T$, Saito $\mathrm{H}$, Katsura $\mathrm{T}$, Inui $\mathrm{K}: A m$. J. Physiol. Gastrointest. Liver Physiol., 291, G851-G856 (2006)

13) Saito H, Terada $T$, Shimakura J, Katsura $T$, Inui $K: A m$. J. Physiol. Gastrointest. Liver Physiol., 295, G395-G402 (2008)

14) Inui K, Masuda S, Saito H : Kidney Int., 58, 944-958 (2000)

15) Koepsell H, Lips K, Volk C : Pharm. Res., 24, 1227-1251 (2007)

16) Yonezawa A, Masuda S, Yokoo S, Katsura T, Inui $\mathrm{K}: J$. Pharmacol. Exp. Ther., 319, 879-886 (2006)

17) Yokoo S, Yonezawa A, Masuda S, Fukatsu A, Katsura T, Inui K : Biochem. Pharmacol., 74, 477-487 (2007)

18) Urakami Y, Kimura N, Okuda M, Inui K : Pharm. Res., 21, 976-981 (2004)

19) Terada T, Inui $\mathrm{K}$ : Biochem. Pharmacol., 75, 1689-1696 (2008)

20) Otsuka M, Matsumoto T, Morimoto R, Arioka S, Omote H, Moriyama Y : Proc. Natl. Acad. Sci. U. S. A., 102, 17923-17928 (2005)

21) Masuda $S$, Terada $T$, Yonezawa A, Tanihara $Y$, Kishimoto K, Katsura T, Ogawa O, Inui K : J. Am. Soc. Nephrol., 17, 2127-2135 (2006)

22) Hori R, Maegawa $\mathrm{H}$, Okano $\mathrm{T}$, Takano $\mathrm{M}$, Inui $\mathrm{K}: J$. Pharmacol. Exp. Ther., 241, 1010-1016 (1987)

23) Hori R, Maegawa $H$, Kato M, Katsura T, Inui $\mathrm{K}$ : J. Biol. Chem., 264, 12232-12327(1989)

24) Ohta K, Inoue K, Hayashi Y, Yuasa H : Drug Metab. Dispos., 34, 1868-1874 (2006) 
25) Asaka J, Terada T, Tsuda M, Katsura T, Inui K : Mol. Pharmacol., 7 1, 1487-1493 (2007)

26) Rizwan AN, Burckhardt G : Pharm. Res., 24, 450-470 (2007)

27) Motohashi H, Sakurai Y, Saito H, Masuda S, Urakami Y, Goto M, Fukatsu A, Ogawa O, Inui K :J. Am. Soc. Nephrol., 13, 866-874 (2002)

28) Ueo H, Motohashi H, Katsura T, Inui, K : Biochem. Pharmacol., 70 1104-1113 (2005)

29) Chen J, Terada $\mathrm{T}$, Ogasawara $\mathrm{K}$, Katsura $\mathrm{T}$, Inui $\mathrm{K}$ : Am. J. Physiol. Renal Physiol., 295, F247-F252 (2008)

30) Hashida T, Masuda S, Uemoto S, Saito H, Tanaka K, Inui K : Clin. Pharmacol. Ther., 69, 308-316 (2001)

31) Masuda S, Inui K : Pharmacol. Ther., 112, 184-198 (2006)

32) Sakurai Y, Motohashi H, Ueo H, Masuda S, Saito H, Okuda M, Mori N, Matsuura M, Doi T, Fukatsu A, Ogawa O, Inui K : Pharm. Res., 21, 61-67 (2004)

33) Sakurai Y, Motohashi H, Ogasawara K, Terada T, Masuda S, Katsura T, Mori N, Matsuura M, Doi T, Fukatsu A, Inui K : Pharm. Res., 22, 2016-2022 (2005)

34) Ogasawara K, Terada T, Motohashi H, Asaka J, Aoki M, Katsura T, Kamba T, Ogawa O, Inui K : J. Hum. Genet., 53, 607-614 (2008)

(Received 25 July 2008;

Accepted 30 July 2008)

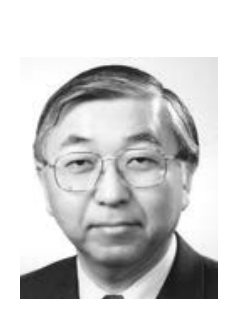

\section{著者略歴}

乾 賢一（いぬい けんいち）

\begin{tabular}{|c|c|}
\hline 1972 年 5 月 & $\begin{array}{l}\text { 広島大学医学部薬学科 } \\
\text { 助手 }\end{array}$ \\
\hline \multirow[t]{2}{*}{ 1978年 3月 } & ハーバード大学医学 \\
\hline & $\begin{array}{l}\text { 部・マサチューセッツ } \\
\text { 総合病院 研究員 }\end{array}$ \\
\hline \multirow[t]{2}{*}{1979 年 10 月 } & 京都大学医学部附属病 \\
\hline & 院薬刘部＼cjkstart助手 \\
\hline 1984年 8月 & $\begin{array}{l}\text { 京都大学医学部附属病 } \\
\text { 院薬剂部 講師 }\end{array}$ \\
\hline 1987年 7月 & $\begin{array}{l}\text { 京都大学医学部附属病 } \\
\text { 院薬剤部 助教授 }\end{array}$ \\
\hline \multirow[t]{2}{*}{ 1990年 2 月 } & 東京医科歯科大学医学 \\
\hline & $\begin{array}{l}\text { 部附属病院薬剂部 教 } \\
\text { 授・薬剤部長 }\end{array}$ \\
\hline \multirow[t]{2}{*}{ 1994年 1月 } & 京都大学医学部附属病 \\
\hline & $\begin{array}{l}\text { 院薬剤部 教授・薬剤 } \\
\text { 部長 }\end{array}$ \\
\hline
\end{tabular}

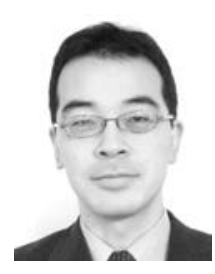

寺田 智祐（てらだ ともひろ）

1999年 3 月 京都大学大学院薬学研 究科博士後期課程修了

1999年 4 月 日本学術振興会特別研 究員 (PD)

2000 年 4 月 京都大学医学部附属病 院薬剤部 助手

2002 年 4 月 ハーバード大学医学 部・マサチューセッツ 総合病院 研究員

2003 年 4 月 京都大学医学部附属病 院薬剤部 助手

2008年 4 月 京都大学医学部附属病 院薬剂部 副薬剤部長 